\title{
Defoliation, waterlogging and dung influences allocation patterns of Deschampsia caespitosa
}

\author{
EVELYN H. MERRILL AND PATRICIA J.S. COLBERG
}

Authors are Associate Professor, Department of Biological Sciences, University of Alberta, Edmonton, Alb. T6G $1 Z 8$ and Associate Professor in the Department of Zoology and Physiology, University of Wyoming, Laramie, Wyo. 82071-3166.

\begin{abstract}
Wet meadows are some of the most productive communities in the northern Rocky Mountains, USA but are also among the most sensitive to grazing by native ungulates and domestic livestock. These meadows typically are inundated with floodwater in spring and early summer but are relatively dry in summer. To determine the interactive effects of clipping and flooding on plant recovery after clipping, we subjected plants of tufted hairgrass (Deschampsia caespitosa (L.) Beauv) to 6-week and 10-week waterlogging treatments in combination with 1 and 2 clipping events, with and without dung amendment in a greenhouse experiment. The experiment was designed to mimic early and late growing-season patterns of herbivory by native and domestic herbivores on a dominant species of wet meadows of this region. Waterlogged plants produced a higher percentage of roots at the surface, elongated stems to the first axial leaf, increased the proportion of tillers that flowered, but increased aboveground yield and tiller height only with the addition of dung. Root biomass declined with waterlogging when dung was not added, and a second defoliation exacerbated the negative effects of waterlogging on roots. Defoliation with short-duration waterlogging increased shoot nitrogen $(N)$ concentration and $N$ yield/root biomass, while continuous waterlogging reduced shoot $N$ concentration of aboveground biomass. Dung amendment did not reverse this effect. Although extended flooding in combination with moderate rates of defoliation did not reduce aboveground biomass of Deschampsia caespitosa, it aggravated total root loss, caused shifts to a shallower root distribution, and altered $\mathbf{N}$ concentration of aboveground biomass for herbivores.
\end{abstract}

Key Words: flooding, tufted hairgrass, herbivory, nitrogen dynamics, wet meadows

Riparian and wet meadow systems are among the most productive foraging areas for both native ungulates and domestic livestock in the western rangelands of the United States; yet they are also among the most sensitive of North American habitats to grazing impact (Johnson et al. 1977). These areas typically are inundated with floodwater in spring and early summer, but are relatively dry in late summer depending on snowpack and the timing of snow melt. Studies in upland systems have shown that plant recovery after defoliation depends largely on environmental

Research was funded by the Basic Research Grants Program at the University of Wyoming.

Manuscript accepted 8 Oct. 02.
Resumen

Las praderas húmedas son una de las comunidades mas productivas del norte de las Montañas Rocallosas del E.U.A, pero también están entre las mas sensitivas al apacentamiento por ungulados nativos y ganado doméstico. Estas praderas típicamente están inundadas en primavera e inicios de verano pero son relativamente secas en el verano. Para determinar el efecto interactivo del corte y la inundación en la recuperación de las plantas después del corte condujimos un experimento de invernadero en el que sometimos plantas de "Tufted hairgrass" (Deschampsia caespitosa (L.) Beauv) a tratamientos de inundación de durante 6 y 10 semanas en combinación con 1 o 2 eventos de corte y con y sin la aplicación de estiércol El experimento se diseñó para simular los patrones de herviboría de inicios y fin de la estación de apacentamiento de los herbívoro nativos y domésticos sobre las especies dominantes de las praderas húmedas de esta región. Las plantas inundadas produjeron un mayor porcentaje de raíces en la superficie, alargaron los tallos en la primer hoja axilar, incrementaron la proporción de hijuelos que florecieron, pero incrementaron el rendimiento de la biomasa aérea y la altura de los hijuelos solo con la adición de estiércol. La biomasa de raíz disminuyó con la inundación cuando no se adiciono estiércol y una segunda defoliación exacerbó los efectos negativos de la inundación en la raíz. La defoliación con cortos periodos de inundación incrementó la concentración de nitrógeno de los tallos $(N)$ y el rendimiento de $\mathrm{N} / \mathrm{biomasas}$ de raíz, mientras que la inundación continua redujo la concentración de $\mathbf{N}$ en los tallos de la biomasa aérea. La incorporación de estiércol no invirtióeste efecto. Aunque la inundación en periodos largos en combinación con tasas moderadas de defoliación no redujeron la biomasa aérea de Deschampsia caespitosa si agravó la perdida total de raíz, causo cambios hacia una distribución de raíz mas superficial y alteró la concentración de $\mathbf{N}$ de la biomasa aérea para los herbívoros.

conditions (Maschinski and Whitham 1989, Georgiadias et al. 1989), yet only a few studies (Middleton 1990, Oesterheld and McNaughton 1991, Gough and Grace 1998, Pacheco 2001) have addressed the effects of flooding on grazing responses outside the flooding Pampa of Argentina (Chaneton et al. 1988, 1996, Rubio et al. 1995, Chaneton and Lavado 1996, Insausti et al. 1999). None of these studies have addressed plants of the northern Rocky Mountain wet meadows.

Oesterheld and McNaughton (1991) suggested that the interactive effects of flooding and defoliation may be more detrimental 
than either effect individually because plants adapted to defoliation or flooding induce largely opposite responses. For example, grazing-tolerant species often respond to defoliation by increasing photosynthetic rates, allocating resources to photosynthetic tissue over roots, and assuming a prostrate growth form (Caldwell et al. 1981, McNaughton 1984, Coughenour et al. 1985). On the other hand, when flooding occurs, roots and microbes rapidly consume available oxygen resulting in anoxic, reduced soils (Kozlowski 1984). Because anoxia interferes with root respiration, flood-tolerant species elongate their stems above the water and develop arenchymatous tissue to allow the transport of oxygen down the shoots to the roots (Crawford 1978); however, since phytotoxins may accumulate under reducing conditions, root permeability may constrain nutrient uptake and water absorption resulting in stomatal closure, reduced photosynthesis, and decreased production (Jackson and Drew 1984, Jackson and Hall 1987). Thus, flooding may hinder the normal plant responses to defoliation such that the timing and frequency of defoliation relative to flooding may be an important determinant of plant response in wet meadow systems.

We designed a greenhouse experiment to compare responses of Deschampsia caespitosa (L.) Beauv to a combination of defoliation and flooding treatments that mimic the conditions this species is subjected to under some management practices in mountain meadows of the northern Rocky Mountains, USA. Typically, domestic cattle are deferred from grazing mountain meadows until mid-summer, but native ungulates use the meadows before the arrival of cattle, moving to higher elevations when cattle arrive in the area (Yeo 1981, Kratville 1989, Kelly 1995). We chose to study tufted hairgrass (Deschampsia caespitosa ) because it is a dominant bunchgrass in wet meadows found between 2,000 and 3,500 $\mathrm{m}$ in elevation throughout the Rocky Mountains, and is grazed by both elk and cattle (Kufield 1973). We hypothesized that: (1) an increase in the duration of flooding would decrease shoot and root biomass and $\mathrm{N}$ concentration; (2) plants defoliated more than once (i.e., similar to combined spring defoliation by elk and summer defoliation by cattle) do not recover as completely as when they are defoliated only once in the growing season, and continuous flooding exacerbates poor plant recovery; (3) flooding produces morphological traits resulting in a higher proportion of biomass vulnerable to fur- ther defoliation; and (4) dung amendment ameliorates declines in biomass and $\mathrm{N}$ concentration in flooded plants.

\section{Material and methods}

Tufted hairgrass plants were collected on 6 May 1993 in high elevational flooded meadows $(2,250 \mathrm{~m})$ near the Laramie River, $10 \mathrm{~km}$ west of Laramie, Wyo. $\left(41^{\circ}\right.$ $\left.18^{\prime} 41^{\prime \prime} \mathrm{N}, 105^{\circ} 35^{\prime} 26^{\prime \prime} \mathrm{W}\right)$, USA. Plants were collected prior to green-up and transported to the greenhouse where tiller number was reduced to 25 , dead leaf material was removed, and roots cut at $10 \mathrm{~cm}$ from the crown-root interface. Plants were placed in pots $(20 \mathrm{~cm}$ diameter $\mathrm{x} 20 \mathrm{~cm}$ height) filled with soils collected from the site, and kept in a greenhouse maintained at $20^{\circ} \mathrm{C}$. Sunlight during the day peaked at $811 \mathrm{~W} \mathrm{~m}^{-2}$ during the experimental period. Plants were watered daily and allowed to grow for 3 weeks prior to the experiment. Three tillers per plant were arbitrarily selected and marked for morphological measurements with thin (diameter $<0.5$ $\mathrm{mm}$ ), plastic-coated wire.

Experimental treatments were initiated on 26 May 1993 when the plants were assigned randomly within a $3 \times 2 \times 2$ factorial design with 8 plants per treatment combination $(n=96)$. Factors and levels were 3 waterlogging treatments (none, 6 weeks [discontinuous], and 10 weeks [continuous]), 2 clipping regimes (clipping only once, clipping twice) and 2 fertilization treatments (none, dung amendment when clipped). We used these treatments in an effort to mimic patterns of herbivory in mountain meadows where native herbivores graze the meadows early in the growing season and then move to higher elevations; the meadows are then used by cattle during the remainder of the growing season (Yeo 1981, Kelly 1995). Flooding consisted of waterlogging potted plants within plastic tubs and maintaining the water level at $0-2 \mathrm{~cm}$ above the soil surface. Pots were re-randomized among flooding tubs every week without allowing the pots to drain. Non-waterlogged plants were watered daily with no additional nutrients added (other than the dung treatments). The first clipping occurred on 26 May while the second clipping occurred on 2 July. All aboveground biomass was removed above $10 \mathrm{~cm}$ from the soil line at each clipping. Fertilization consisted of applying wet weight of fresh elk dung after first clipping and cattle dung after second clipping. Fresh feces were collected from penned elk fed alfalfa at the
University of Wyoming's Red Buttes Environmental Biology Laboratory and from cattle grazing shortgrass prairie near Laramie, Wyo. Dung samples were combined and mixed (as much as dung form would allow) prior to application. Based on Kjeldahl analysis (Bradstreet 1965) of percent $\mathrm{N}$ for 5 arbitrarily collected subsamples of each type of dung, $\mathrm{N}$ applied in elk dung was $53.7 \mathrm{~kg} / \mathrm{ha}$ and cattle dung at $46.8 \mathrm{~kg} / \mathrm{ha}$.

Prior to plant harvest on 4 August 1993, we counted the number of vegetative and reproductive tillers per plant and measured height of marked tillers, distance from the soil line to the first basal leaf, number of leaves per vegetative tiller, and length of the first axial leaf. Harvested plants were separated into aboveground biomass, surface roots $(<2.5 \mathrm{~cm}$ from soil surface), and bottom roots $(>2.5 \mathrm{~cm})$. Plant materials were oven-dried for 48 hours at $50^{\circ} \mathrm{C}$, and weighed and analyzed for Kjeldahl N. Soil samples from just below the soil surface and at about $8 \mathrm{~cm}$ below the soil surface were taken from half of the plants in each treatment combination $(n=48)$ and analyzed for ammonium and nitrate at the University of Wyoming Soils Testing Laboratory using an autoanalyzer.

Analysis of variance and Tukey's highly significant difference test (Zar 1996) were used to detect differences in treatment means and interactions. Plant yield was determined as standing crop at harvest plus clipped biomass. Total $\mathrm{N}$ yield was estimated from above ground plant yield and $\mathrm{N}$ concentration at harvest. Except for tiller height, biomass and morphological measurements were transformed using a $\log$ transformation prior to analysis. Percent $\mathrm{N}$ values were transformed using arcsine square-root transformation prior to analysis because values were below $30 \%$ (Zar 1996). Differences were considered significant at $\alpha \leq 0.10$.

\section{Results}

Waterlogging had no effect on standing, aboveground biomass at the end of the experiment unless dung was added, and plant yield increased (160 to $240 \%$ ) only with waterlogging and dung amendment compared to no flooding and dung treatments (Table 1, Fig. 1). Tillers of waterlogged plants were taller than non-waterlogged plants when they were not clipped a second time, and the height difference was most pronounced when plants were waterlogged and dung was not added (Fig. 2a). Twice clipping consistently reduced 
Table 1. Significance levels for ANOVA differences among treatment means and interactions among waterlogging (W), clipping (C), and dung amendments (D) on Deschampsia caespitosa $(\mathbf{L}$.) Beauv ns $=\mathbf{P}>0.10$.

\begin{tabular}{|c|c|c|c|c|c|c|c|}
\hline & W & $\mathrm{C}$ & $\mathrm{D}$ & $\mathrm{F} \times \mathrm{C}$ & $\mathrm{C} \times \mathrm{D}$ & $\mathrm{F} \times \mathrm{D}$ & FxCxD \\
\hline Aboveground yield & 0.001 & 0.001 & 0.001 & 0.015 & ns & 0.001 & ns \\
\hline Aboveground biomass & 0.001 & 0.005 & 0.001 & 0.013 & ns & 0.013 & 0.014 \\
\hline Total root biomass & ns & 0.001 & 0.000 & 0.000 & ns & 0.000 & .012 \\
\hline Surface root biomass (\%) & 0.017 & $\mathrm{~ns}$ & ns & ns & ns & ns & ns \\
\hline Number tillers/plant & 0.008 & ns & 0.001 & 0.091 & ns & 0.001 & 0.090 \\
\hline Reproductive tillers (\%) & 0.045 & ns & 0.001 & ns & ns & 0.001 & ns \\
\hline Tiller height & 0.002 & 0.001 & 0.020 & 0.017 & 0.014 & ns & ns \\
\hline Leaves/vegetative tiller & 0.001 & 0.041 & ns & 0.060 & $\mathrm{~ns}$ & 0.001 & ns \\
\hline Leaf length & 0.001 & .001 & .001 & ns & ns & ns & ns \\
\hline Distance to first leaf & 0.001 & $\mathrm{~ns}$ & ns & ns & ns & 0.001 & ns \\
\hline Green shoot N (\%) & 0.001 & ns & ns & 0.005 & ns & 0.001 & ns \\
\hline Surface root N (\%) & 0.030 & ns & 0.001 & ns & ns & ns & ns \\
\hline Basal root $\mathrm{N}(\%)$ & 0.000 & ns & ns & 0.008 & ns & ns & 0.025 \\
\hline $\begin{array}{l}\mathrm{N} \text { uptake } \\
\text { ( } \mathrm{N} \text { in harvested + clipped } \\
\text { biomass/root biomass) }\end{array}$ & 0.001 & 0.001 & 0.016 & 0.001 & ns & 0.001 & ns \\
\hline Soil $<2.5 \mathrm{~cm} \mathrm{NH}_{4}^{+}-\mathrm{N}$ & 0.031 & ns & ns & ns & ns & 0.012 & ns \\
\hline Soil $<2.5 \mathrm{~cm} \mathrm{NO}_{3}^{-}-\mathrm{N}$ & ns & 0.083 & ns & ns & ns & ns & ns \\
\hline
\end{tabular}

leaf lengths while waterlogging increased leaf lengths. Dung amendment exaggerated these effects (Fig. 2b). Only waterlogging had an effect on the distance to the first axial leaf, with average distances increasing by $6-12 \mathrm{~mm}$ when no dung was added and 14-22 $\mathrm{mm}$ when dung was added (Fig. 2c). Waterlogging had little effect on the number of leaves/tiller when dung was added, but reduced the number of leaves on plants without dung that were clipped twice in the growing season (Fig. 2d). Waterlogging decreased the number of tillers and increased the proportion of reproductive tillers in plants (Fig. 3); how- ever, the addition of dung reversed this effect.

Root responses varied even more by treatment than did aboveground growth. When dung was not added, total root biomass declined an average of $22 \%$ with discontinuous waterlogging and $33 \%$ with continuous waterlogging, with the greatest reduction observed in plants clipped twice in the growing season (Fig. 1). At the end of the experiment, root biomass was highest in plants that were discontinuously waterlogged, clipped only once in the season, and amended with dung. Plants exhibited a greater proportion of root bio-

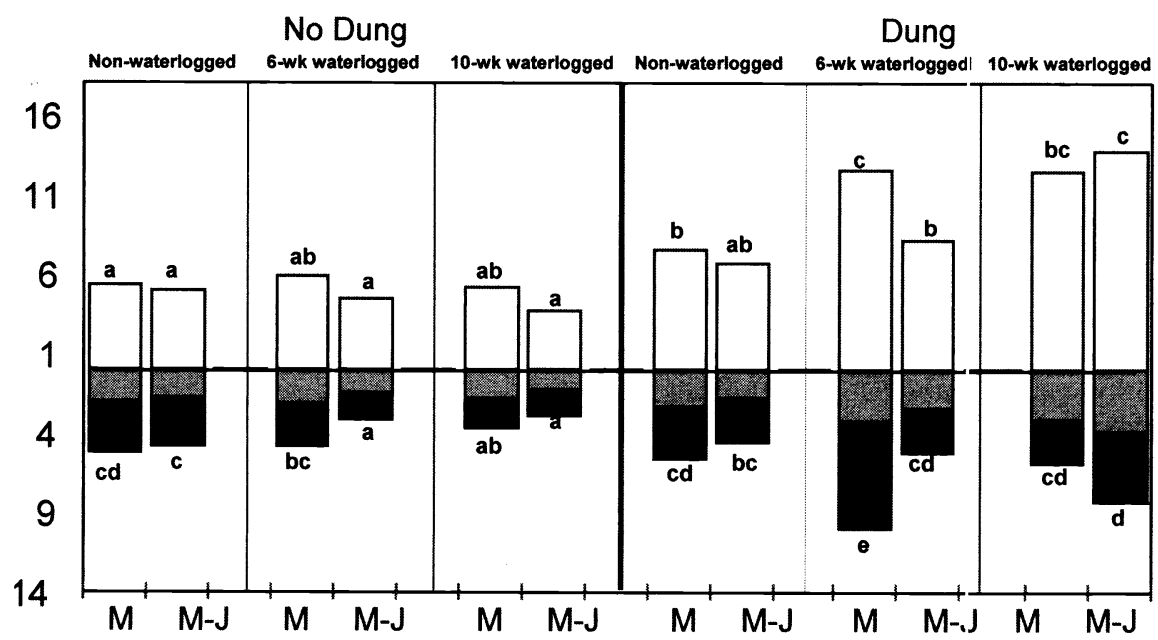

Aboveground

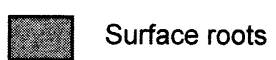

Basal rocts

Fig. 1. Aboveground standing biomass and root biomass (g/plant) of Deschampsia caespitosa (L.) Beauv plants harvested 10 weeks after initiation of 3 treatments: waterlogging for 0,6 and 10 weeks; clipping once in May (E) and once in May and July (L) clipping to $10 \mathrm{~cm}$; and no dung addition or dung addition with clipping once or clipping twice. Surface roots were collected $<2.5 \mathrm{~cm}$ from soil surface. Means with the same letters are not significantly different at $\alpha=0.10$ across all treatments. mass at the surface when plants were waterlogged (Fig. 1).

Continuous, but not discontinuous, waterlogging reduced shoot $\mathrm{N}$ at the end of the experiment, and dung amendment only partially ameliorated this effect (Table 2). Discontinuously waterlogged plants that were clipped twice had higher shoot $\mathrm{N}$ than plants clipped only once in the growing season. While this was consistent across dung treatments, the difference was significant only when dung was not added. Surface root $N$ generally was higher when dung was added (Table 2). Nitrogen dynamics in basal roots were more complex. Overall, waterlogging reduced basal root $\mathrm{N}$; the clipping regime influenced basal root $\mathrm{N}$ but only when dung was added. The nature of the effect depended on the duration of waterlogging. Nitrogen uptake, as reflected by the ratio of total $\mathrm{N}$ yield to root biomass, was higher in twice clipped plants and was most pronounced in plants that were discontinuously waterlogged (Table 2).

Ammonium ion concentration was higher (Paired t-test, $\mathrm{t}_{\mathrm{df}=94}=-2.026, \mathrm{P}=$ $0.046)$ in samples taken from the soil surface $(0-2.5 \mathrm{~cm})$ than in samples taken deeper in the soil, while there was no difference $\left(\mathrm{t}_{\mathrm{df}}=94=-1.365 \mathrm{P}=0.176\right)$ in nitrate concentrations. Treatment differences in soil $\mathrm{N}$ occurred only in the upper, but not the lower soils (Table 2). Ammonium accumulated with flooding, whereas nitrate levels were lower in soils of plants clipped twice in the season. 

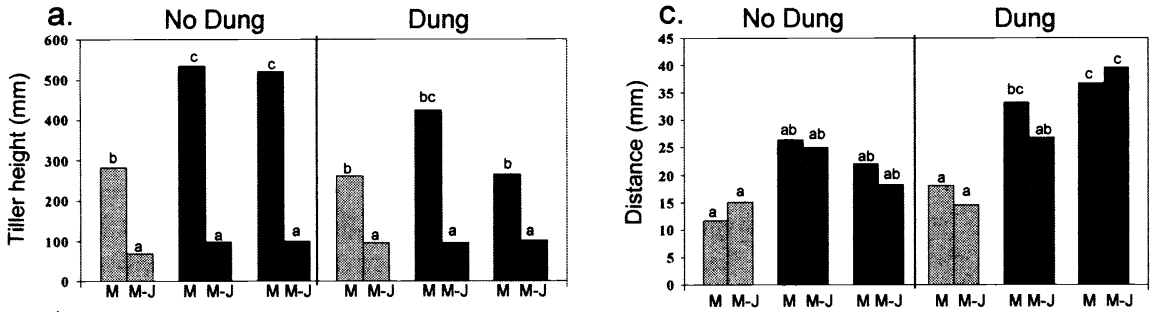

$$
\text { b. }
$$
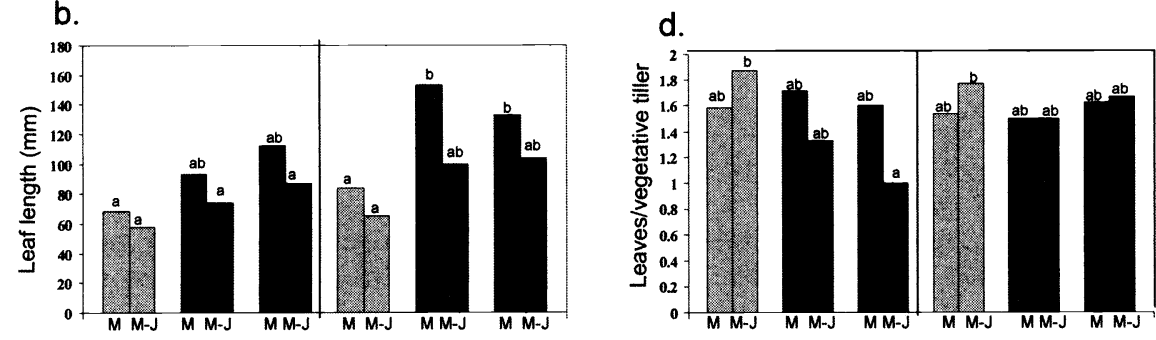

No waterlogging 6 -wk waterlogging $\square$ 10-wk waterlogging

Fig. 2. Average tiller height (a), length of first axial leaf (b), distance from soil line to first axial leaf (c), and number of leaves/vegetative tiller (d) of Deschampsia caespitosa (L.) Beauv plants harvested 10 weeks after initiation of waterlogging, clipping and fertilization treatments. Treatments as described in Fig. 1. Means with the same letters are not significantly different at $\alpha=0.10$ across all treatments.

\section{Discussion}

Contrary to our hypothesis, duration of waterlogging neither reduced aboveground production nor aggravated the effects of a second defoliation on standing biomass or yield of tufted hairgrass under greenhouse conditions. Tufted hairgrass is characteristic of wet soils and is well adapted to anoxic soils associated with waterlogging (Lawrence 1945, Davy and Taylor 1974, Rahman 1976, Rahman and Rutter 1980, Theodose and Bowman
1997), but when subjected to heavy defoliation by ungulates, it generally is replaced by Kentucky bluegrass (Poa sandbergii L.) (Padgett et al. 1989). Clipping to a 10$\mathrm{cm}$ stubble height was used in this study because this is the criterion sometimes used in mountainous areas of the northern Rocky Mountains of the USA for removing cattle from the range (Kelly 1995). At this level of defoliation, tufted hairgrass has the potential to recover from the combined effects of these disturbances, which may explain why it remains common in wet meadows where grazing is managed, but declines where grazing pressure is high (Padgett et al. 1989).

Oesterheld and McNaughton (1991) hypothesized that the negative interactive effects of flooding and grazing found in total yield of Serengeti grasses resulted from preferential allocation to support tissue (stems) because of their lower photosynthetic rates. Increased distance to the first axial leaf and tiller height observed in our experiment are generally consistent with this hypothesis, yet we found no reduction in aboveground biomass with flooding and defoliation. Instead, the increase in tiller height was associated with a shift to fewer, but taller, flowering tillers. Similar shifts in flowering culms have been reported for Sporabolus virginicus (L. Kunth.) in response to flooding (Naidoo and Naidoo 1992, Naidoo and

Table 2. Nitrogen yield/root $(\mathrm{g} / \mathrm{g})$, shoot, surface root, and basal root nitrogen $(\% \mathrm{~N})$, and soil ammonium $\left(\mathrm{NH}_{4}{ }^{+}\right)$and nitrate $\left(\mathrm{NO}_{3}{ }^{-}\right)$concentrations ( $\mathrm{mg} / \mathrm{kg}$ ) of soils collected $<2.5 \mathrm{~cm}$ and $>8 \mathrm{~cm}$ below the soil surface from pots in which Deschampsia caespitosa was grown. Treatments included 3 flooding levels (no flooding, 6-weeks, 10-weeks), 2 clipping frequencies (26 May, 26 May and 2 July), and 2 dung amendment levels (none, or elk dung with first clipping and cow dung with second clipping).

\begin{tabular}{|c|c|c|c|c|c|c|c|c|}
\hline \multirow{3}{*}{\multicolumn{2}{|c|}{$\begin{array}{cc}\text { N yield/root } \\
(\mathrm{g} / \mathrm{g})\end{array}$}} & \multirow{3}{*}{$\begin{array}{c}\text { Shoot } \\
\mathrm{N} \\
(\%)\end{array}$} & \multirow{3}{*}{$\begin{array}{c}\text { Surface } \\
\text { Root N } \\
(\%)\end{array}$} & \multirow{3}{*}{$\begin{array}{c}\text { Basal } \\
\text { Root N } \\
(\%)\end{array}$} & \multicolumn{2}{|c|}{ Surface soil } & \multicolumn{2}{|c|}{ Lower soil } \\
\hline & & & & & $\mathrm{NH}_{4}^{+}$ & $\mathrm{NO}_{3}{ }^{-}$ & \multicolumn{2}{|c|}{$\mathrm{NH}_{4}^{+} \mathrm{NO}_{3}^{-}$} \\
\hline & & & & & $(\mathrm{mg} / \mathrm{kg})$ & $(\mathrm{mg} / \mathrm{kg})$ & $(\mathrm{mg} / \mathrm{kg})$ & $(\mathrm{mg} / \mathrm{kg})$ \\
\hline \multicolumn{9}{|c|}{$\begin{array}{l}\text { No dung amendment } \\
\text { No flooding }\end{array}$} \\
\hline Clipped once & $2.56 \mathrm{ab}$ & $1.32 \mathrm{~b}$ & $0.83 \mathrm{a}$ & $1.30 \mathrm{ab}$ & $1.93 \mathrm{ab}$ & $0.83 \mathrm{ab}$ & 1.73 & 0.93 \\
\hline Clipped twice & $3.06 \mathrm{ab}$ & $1.28 \mathrm{~b}$ & $0.80 \mathrm{a}$ & $1.34 \mathrm{ab}$ & $1.03 a$ & $0.78 \mathrm{ab}$ & 1.83 & 0.65 \\
\hline \multicolumn{9}{|c|}{ Intermittent flooding } \\
\hline Clipped once & $3.34 \mathrm{ab}$ & $1.47 \mathrm{~b}$ & $0.95 \mathrm{ab}$ & $1.26 a b$ & $2.15 \mathrm{ab}$ & $0.90 \mathrm{ab}$ & 1.40 & 0.87 \\
\hline Clipped twice & $6.28 \mathrm{c}$ & $1.82 \mathrm{c}$ & $0.94 \mathrm{ab}$ & $1.28 \mathrm{ab}$ & $2.40 \mathrm{ab}$ & $0.78 \mathrm{ab}$ & 1.82 & 0.75 \\
\hline \multicolumn{9}{|c|}{ Continuous flooding } \\
\hline Clipped once & $2.46 \mathrm{a}$ & $0.95 \mathrm{a}$ & $0.85 a$ & $1.23 \mathrm{ab}$ & $3.85 \mathrm{ab}$ & $0.88 \mathrm{ab}$ & 2.50 & 0.75 \\
\hline Clipped twice & $3.44 a b$ & $0.87 \mathrm{a}$ & $0.87 \mathrm{a}$ & $1.19 \mathrm{ab}$ & $5.88 \mathrm{~b}$ & $0.93 a b$ & 2.38 & 0.75 \\
\hline \multicolumn{9}{|l|}{ Dung amendment } \\
\hline No flooding & & & & & & & & \\
\hline $\begin{array}{l}\text { Clipped once } \\
\text { Clipped twice }\end{array}$ & $4.75 b c$ & $1.58 \mathrm{bc}$ & $0.95 \mathrm{ab}$ & $1.48 \mathrm{~b}$ & $2.35 \mathrm{ab}$ & $1.08 \mathrm{ab}$ & 2.50 & 0.83 \\
\hline Clipped twice & $4.68 b c$ & $1.49 \mathrm{bc}$ & $0.92 \mathrm{ab}$ & $1.46 \mathrm{~b}$ & $2.78 \mathrm{ab}$ & $0.90 \mathrm{ab}$ & 2.05 & 0.78 \\
\hline \multicolumn{9}{|c|}{ Intermittent flooding } \\
\hline Clipped once & $2.37 \mathrm{a}$ & $1.06 \mathrm{ab}$ & $0.95 \mathrm{ab}$ & $0.97 \mathrm{a}$ & $5.45 \mathrm{~b}$ & $0.88 \mathrm{ab}$ & 4.50 & 0.87 \\
\hline Clipped twice & $5.57 \mathrm{c}$ & $1.52 \mathrm{bc}$ & $1.12 \mathrm{c}$ & $1.38 \mathrm{ab}$ & $3.15 \mathrm{ab}$ & $0.75 \mathrm{ab}$ & 2.55 & 0.87 \\
\hline \multicolumn{9}{|c|}{ Continuous flooding } \\
\hline Clipped once & $3.91 \mathrm{~b}$ & $1.21 \mathrm{ab}$ & $1.08 \mathrm{c}$ & $1.25 \mathrm{ab}$ & $2.52 \mathrm{ab}$ & $1.40 \mathrm{~b}$ & 1.95 & 0.87 \\
\hline Clipped twice & $3.87 \mathrm{~b}$ & $1.05 \mathrm{ab}$ & $1.01 \mathrm{bc}$ & $1.02 \mathrm{a}$ & $3.18 \mathrm{ab}$ & $0.68 \mathrm{a}$ & 1.77 & 0.85 \\
\hline
\end{tabular}

${ }^{1}$ Different letters indicate significant $(\alpha=0.10)$ differences among treatments within a column. 

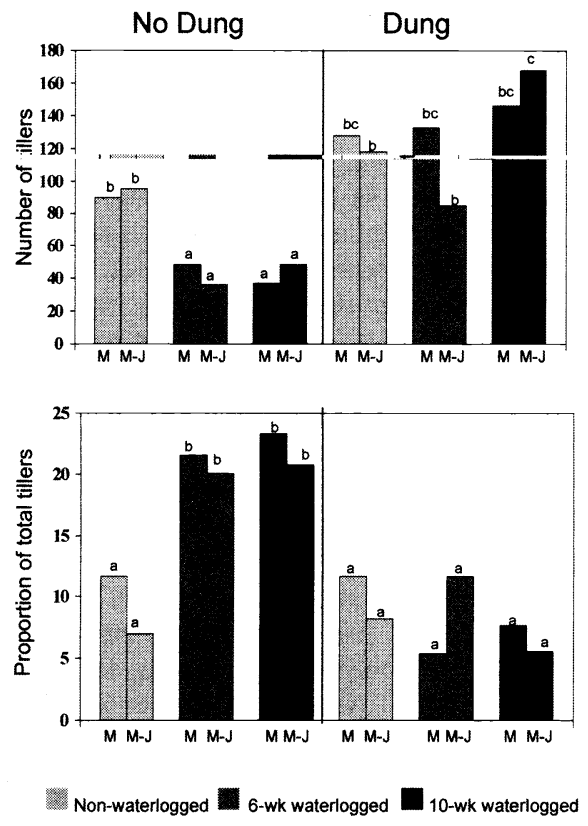

Fig. 3. Number of tillers per plant (a) and proportion of flowering tillers (b) of Deschampsia caespitosa (L.) Beauv plants harvested 10 weeks after initiation of waterlogging, clipping and fertilization treatments. Treatments as described in Fig 1. Means for above ground biomass and total root biomass with the same letters are not significantly different at $\alpha=$ 0.10 across all treatments.

Mundee 1993) and may be triggered by high ammonium concentrations in the surface soils (Ruess et al. 1983). Such a strategy can provide for seed bank enhancement or dispersal of seeds across flooded areas (Kirkman and Sharitz 1993).

In contrast to aboveground responses, waterlogging resulted in reductions in total root biomass as well as a change in root distribution when dung was not added. Although an increase in surface roots may promote oxygen diffusion to the rhizosphere, maintenance of total root biomass in anoxic, flooded soils typically requires a well-developed aerenchyma system. Tufted hairgrass is reported to have a moderately high capacity for aerenchyma in its roots, likely providing oxygen storage for short term needs, but is insufficient to maintain aerobic respiration under continual flooding (Crawford 1978).

Lower shoot $\mathrm{N}$ in continually flooded plants and increased plant production both above- and belowground with dung amendment indicates a nutrient limitation under continuous waterlogged conditions. Nevertheless, lower root:shoot ratios in flooded, tufted hairgrass plants indicate that lower root biomass under waterlog- ging sustained aboveground production (Fig. 1.). Likewise, laboratory experiments with barley plants have reported reductions in $\mathrm{N}$ uptake without reductions in dry matter accumulation when plants were flooded (Leyshon and Sheard 1975, Drew and Sisworo 1979). Oesterheld and McNaughton (1991) suggested that aboveground yield can be maintained in flooded plants by some degree of compensation in root function. Our estimates of aboveground $\mathrm{N}$ yield/root biomass support an increase in $\mathrm{N}$ uptake with defoliation, but not with flooding. Alternatively, the decline in $\mathrm{N}$ concentration without a decline in aboveground production in continually flooded plants may have resulted from increased $\mathrm{N}$-use efficiencies that occur under relatively low nitrate soil levels (Jiang and Hull 1998) and that are associated with both an abundance of ammonium and an increase in flowering. Selection for flexible $\mathrm{N}$-use efficiencies in flood-tolerant plants may be an important adaptation in productive wet meadow communities, since competition for light can be high and waterlogged soils limit nutrient uptake.

Despite the patchy distribution of dung, its importance in promoting plant production in wetland systems has been demonstrated in experimental applications of ammonium, nitrate, and goose feces in the field (Cargill and Jefferies 1984, Bazely and Jefferies 1985). Although the amount of dung we added to our pots was high, it was similar to what we observed in small areas around individual plants in wet meadows and fell within the range of $127-823 \mathrm{mg} \mathrm{N} / \mathrm{m}^{2}$ reported in areas intensively grazed by geese (Hik et al. 1991). The simplest explanation for increased growth in continuously flooded plants is that flooding makes soluble $\mathrm{N}$, and other nutrients readily available to plants (Bazely and Jefferies 1985). The higher biomass of surface roots in flooded plants may facilitate $\mathrm{N}$ uptake at the oxidized soil-water interface when dung is deposited, making nutrient return by animals more readily available for plant in wet meadow systems compared to upland systems. Nonetheless, if flooding enhances nutrient availability where dung occurs, this does not appear to translate into higher $\mathrm{N}$ shoot concentration as has been found in upland systems with grazing (Holland and Detling 1990, Merrill et al. 1994). Instead, increased aboveground production with flooding had a diluting effect on shoot $\mathrm{N}$ concentration. Thus, while total $\mathrm{N}$ available to herbivores may increase, total $\mathrm{N}$ per bite may decrease.
High $\mathrm{N}$ yield/root biomass and shoot $\mathrm{N}$ under discontinuous flooding and clipping may involve several mechanisms. First, the rate of ammonium loss, which accumulated under flooding in the upper soil, may decrease under rapid drying of the soil (Ferguson and Kissel 1986). The pool of ammonium may have increased availability of nitrates under improved soil conditions. Nitrate diffuses more readily in the soil (Barber 1984) and is readily taken up by defoliated plants because clipping has a stimulatory effect on nitrate uptake (Ruess et al. 1983). We did not observe increased nitrate in discontinuously flooded soils; however, a decline in nitrate occurred with defoliation across treatments. Alternatively, root mortality associated with defoliation may create a readily available carbon source for microorganisms (Holland and Detling 1990, Merrill et al. 1994, Bardgett et al. 1998), which may result in high mineralization rates under improved aerobic conditions in the soil. Indeed, higher mineralization rates have been reported in the flooding Pampa that is grazed (Chaneton et al. 1996).

While our experiment does not replicate natural conditions, field observations on the aboveground response of tufted hairgrass to grazing and flooding independently support our results that hairgrass remains abundant under temporarily flooded conditions and under moderate grazing levels, but declines in unflooded uplands and under heavy grazing (Davy and Taylor 1974, Padgett et al. 1989). We know of no studies that have examined root responses to the combination of these factors in the field. Changes in biomass and nitrogen allocation patterns resulting from interactions among flooding, defoliation, and dung deposition may have several implications for wet meadow grazing systems. First, grazing to a particular plant height (e.g., $10 \mathrm{~cm}$ ), as is commonly practiced (Kelly 1995, Dovel 1996), may produce higher rates of defoliation than believed because plant height increases with flooding; the amount of biomass removed in our clipping treatments was correlated with plant height $(\mathrm{r}=0.73, \mathrm{P}=$ $0.01, \mathrm{n}=96$ ). Second, flooding can result in reduced root biomass, and a second defoliation appears to aggravate this loss. Finally, although flooding may not reduce aboveground plant production in tufted hairgrass communities under moderate defoliation (Bonham 1972), particularly where dung deposition is heavy, duration of flooding may play an important role in altering aboveground plant $\mathrm{N}$ concentration and $\mathrm{N}$ return to the animal. 


\section{Literature Cited}

Barber, S.A. 1984. Soil nutrient bioavailability. Wiley and Sons, New York, N.Y.

Bardgett, R.D., D.A. Wardle, and G.W. Yeates. 1998. Linking above-ground and below-ground interactions: how plant responses to foliar herbivory influence soil organisms. Soil Biol. Biochem. 30:1867-1878.

Bazely, D.R. and R.L. Jefferies. 1985. Goose faeces: a source of nitrogen for plant growth in a grazed salt marsh. J. Appl. Ecol. 22:693-703.

Bonham, C.D. 1972. Vegetation analysis of grazed and ungrazed alpine hairgrass meadows. J. Range Manage. 25:276-279.

Bradstreet, R.B. 1965. The Kjeldahl method for organic nitrogen. Academic Press, New York, N.Y.

Caldwell, M., M. Richards, J.H.D.A. Johnson, R.S. Nowak, and R.S. Dzuree. 1981. Coping with herbivory: photosynthetic capacity and resource allocation in 2 semiarid Agropyron bunchgrasses. Oecologia 50:14-24.

Cargill, S.M. and R.L. Jefferies. 1984. Nutrient limitation of primary production in a sub-arctic salt marsh. J. Appl. Ecol. 21:657-668.

Chaneton, E.J. and R.S. Lavado. 1996. Soil nutrients and salinity after long-term grazing exclusion in a flooding Pampa grassland. J. Range Manage. 49:182-187.

Chaneton, E.J., J.M. Facelli, and R.J.C. Leon. 1988. Floristic changes induced by flooding on grazed and ungrazed lowland grasslands in Argentina. J. Range Manage. 41:495-499.

Chaneton, E.J., J.H. Lemcoff, and R.S. Lavado. 1996. Nitrogen and phosphorous cycling in grazed and ungrazed plots in a temperate subhumid grassland in Argentina. J. Appl. Ecol. 33:291-302.

Coughenour, M.B., S.J. McNaughton, and L.L. Wallace. 1985. Responses of African tall-grass (Hyparrhenia filipendula) to defoliation and limitations of water and nitrogen. Oecologia 68:80-86.

Crawford, R.M.M. 1978. Metabolic adaptations to anoxia, p. 119-136. In: D.D. Hook and R. Crawford, (eds.) Plant life in anaerobic environments. Ann Arbor Press, Ann Arbor, Mich.

Davy, A.J. and K. Taylor. 1974. Water characteristics of contrasting soils in the Chiltern Hills and their significance for Deschampsia caespitosa (L.) Beauv. J. Ecol. 62:372-378.

Dovel, R.L. 1996. Cutting height effects on wetland meadow forage yield and quality. J. Range Manage. 49:151-156.

Drew, M.C. and E.J. Sisworo. 1979. The development of waterlogging damage in young barley plants in relation to plant nutrient status and changes in soil properties. New Phytol. 82:301-314.

Ferguson, R.B. and D.E. Kissel. 1986. Effects of soil drying on ammonia volatilization from surface-applied urea. Soil Sci. Soc. Amer. J. 50:485-490.
Georgiadias, N.J., R.W. Ruess, S.J. McNaughton, and D. Western. 1989. Ecological conditions that determine when grazing stimulates grass production. Oecologia 81:870-892.

Gough, L. and J.B. Grace. 1998. Effects of flooding, salinity and herbivory on coastal plant communities, Louisiana, United States. Oecologia 117:527-535.

Hik, D.S., H.A. Sadul, and R.L. Jefferies. 1991. Effects of the timing of multiple grazing by geese on net above-ground primary production of swards of Puccinella phryganodes. J. Ecol. 79:715-730.

Holland, E.A. and J.K. Detling. 1990. Plant response to herbivory and belowground nitrogen cycling. Ecol. 71:1040-1049.

Insausti, P., E.J. Chaneton, and A. Soriano. 1999. Flooding reverted grazing effects on plant community structure in mesocosm of lowland grassland. Oikos 84:266-276.

Jackson, M.B. and M.C. Drew. 1984. Effects of flooding on growth and metabolism of herbaceous plants, p. 47-128. In: T.T. Kozlowski (ed.) Flooding and plant growth. Academic Press, London.

Jackson, M.B. and K.C. Hall. 1987. Early stomatal closure in waterlogged pea plants is mediated by abscisic acid in the absence of foliar water deficits. Plant Cell Environ. 10:121-130.

Jiang, Z.C. and R.J. Hull. 1998. Interrelationships of nitrate uptake, nitrate reductase, and nitrogen use efficiency in selected Kentucky bluegrass cultivars. Crop Sci. 6:1623-1632.

Johnson, R.R., L.T. Hight, and J.M. Simpson. 1977. Endangered species vs. endangered habitats: a concept, p. 68-79. In: Importance, preservation and management of riparian habitat. USDA For. Serv. Gen. Tech. Rep. RM-43. Washington, D.C.

Kelly, S.M. 1995. Elk and cattle range relations on the Lemhi Mountains, Idaho. M.S. Thesis. Dept. Zool. and Physiol., Univ. of Wyoming, Laramie, Wyo.

Kirkman L.K. and R.R. Sharitz. 1993. Growth in controlled water regimes of three grasses common in freshwater wetlands of the southeastern USA. Aquatic Bot. 44:345-359.

Kozlowski, T.T. 1984. Plant responses to flooding of soil. BioSci. 34:162-167.

Kratville, S.P. 1989. Elk habitat selection, distribution, and nutrition as influenced by cattle in east-central Idaho. M.S. Thesis. Univ. of Montana, Missoula, Mont.

Kufield, R.C. 1973. Foods eaten by the Rocky Mountain elk. J. Range Manage. 26:106-113.

Lawrence, W.E. 1945. Some ecotypic relations of Deschampsia caespitosa. Amer. J. Bot. 32:298-314.

Leyshon, A.J. and R.W. Sheard. 1975. Influence of short-term flooding on the growth and plant nutrient composition of barley. Can. J. Soil Sci. 54:463-471.

Maschinski, J. and T.G. Whitham. 1989. The continuum of plant responses to herbivory: influence of plant association, nutrient availability and timing. Am. Nat. 134:1-19.
McNaughton, S.J. 1984. Grazing lawns: animals in herds, plant form, and coevolution. Amer. Nat. 124:863-886.

Merrill, E.H., N.L. Stanton, and H.C. Hak. 1994. Responses of bluebunch wheatgrass, Idaho fescue, and nematodes to ungulate grazing in Yellowstone National Park. Oikos 69:231-240.

Middleton, B.A. 1990. Effect of water depth and clipping frequency on the growth and survival of four wetland plant species. Aquatic Bot. 37:189-196.

Naidoo, G. and S. Naidoo. 1992. Waterlogging responses of Sporobolus virginicus (L.) Kunth. Oecologia 90:445-450.

Naidoo, G. and S.G. Mundee. 1993. Relationship between morphological and physiological repsonses to waterlogging and salinity in Sporobolus virginicus (L.) Kunth. Oecologia 93:360-366.

Oesterheld, M. and S.J. McNaughton. 1991. Interactive effects of flooding and grazing on the growth of Serengeti grasses. Oecologia 88:153-156.

Pacheco, M.W. 2001. Effects of flooding and herbivores on variation in recruitment of palms between habitats. J. Ecol. 89:358-366.

Padgett, W.G., A.P. Youngblood, and A.H. Winward. 1989. Riparian community type classification of Utah and Southeastern Idaho. USDA For. Serv. H4-Ecol-89-01.

Rahman, M.S. 1976. A comparison of the ecology of Deschampsia caespitosa (L.) Beau. and Dactylis glomerata (L.) in relation to the water factor. I. Studies in field conditions. J. Ecol. 64:449-462.

Rahman, M.S. and A.J. Rutter. 1980. A comparison of the ecology of Deschampsia caespitosa and Dactylis glomerata in relation to the water factor. II. Controlled experiments in glasshouse conditions. J. Ecol. 68:479-491.

Rubio, G., G. Casasola, and R.S. Lavado. 1995. Adaptations and biomass production of two grasses in response to waterlogging and soil nutrient enrichment. Oecologia 102:102-105.

Ruess, R.W., S.J. McNaughton, and M.B. Coughenour. 1983. The effects of clipping, nitrogen source and nitrogen concentration on the growth responses and nitrogen uptake of an east African sedge. Oecologia 3:253-261.

Theodose, T.A. and W.D. Bowman. 1997. The influence of interspecific competition on the distribution of an alpine graminoid: evidence for the importance of plant competition in an extreme environment. Oikos 79:101-114.

Yeo, J.J. 1981. The effects of rest-rotation grazing on mule deer and elk populations inhabiting the Herd Creek allotment, East Fork Salmon River, Idaho. M.S. Thesis. Univ. of Idaho, Moscow, Ida.

Zar, J.H. 1996. Biostatistical Analysis. Prentice Hall, Upper Saddle River, N.J. 